\title{
The Prevalence of Vote Buying in Indonesia: Building an Index
}

How prevalent is patronage distribution in Indonesia? Although there has been a burst of scholarly and non-scholarly writings on the topic in the last few years, ${ }^{1}$ little is known about how many voters actually receive material incentives from politicians. This chapter offers a systematic answer to fundamental questions about the intensity of money politics in Indonesia that have vexed scholars for many years. It involves a complex study of patronage politics in Indonesian elections, which draws predominantly on surveys. ${ }^{2}$

\footnotetext{
${ }^{1}$ Among others, Choi (2007), Aspinall (2014), Allen (2015), Aspinall and As'ad (2015), Aspinall and Sukmajati (2016), Aspinall et al. (2017), Amick (2016), and Tawakkal et al. (2017).

${ }^{2} \mathrm{I}$ used a number of nationwide surveys in this chapter, including an April 2009 survey by The Indonesian Survey Institute (LSI) and a December 2013 survey by Saiful Mujani Research and Consulting (SMRC). The LSI survey took place from 20 to 27 April 2009, approximately one week after the legislative election. The sample was 2000 voting-age adults with a margin of error of $\pm 2.4 \%$ at $95 \%$ confidence level. Meanwhile, the SMRC survey interviewed 1210 respondents, who, like the respondents in the LSI poll, were selected with multistage random sampling, with an estimated margin of error of $\pm 2.9 \%$ at $95 \%$ confidence level. This chapter also draws from a pre-election survey conducted during 19-24 March 2014. The number in the sample was 1220 voting-age adults who were selected with multistage random sampling proportionally distributed over the 34 provinces. The margin of error was around $\pm 2.9 \%$ at $95 \%$ significance level. However, this chapter draws primarily from my post-legislative election survey conducted during 22-26 April 2014, around two weeks after the legislative election. I timed the surveys to take advantage of a simultaneous national and sub-national parliamentary election held on 9 April 2014, which would mean that citizens' recent interactions with parties, candidates, and brokers were fresh in their minds. In addition to these national surveys, I also utilised a large amount of data drawn from 963 local surveys conducted by LSI and Indikator Politik along with SMRC from 2006 to 2015.
}

(C) The Author(s) 2019

B. Muhtadi, Vote Buying in Indonesia, https://doi.org/10.1007/978-981-13-6779-3_2 
In this chapter, to measure the intensity of vote buying, I use a votebuying index as the main dependent variable of this study. I argue that vote buying is central to election campaigns in Indonesia. Drawing from a wide range of survey methods, I estimate that the proportion of voters participating in vote buying during the 2014 legislative election was between $25 \%$ and $33 \%$ (depending on the method and specific question used in the survey). For comparative purposes, I relate this figure of selfreported vote buying with rates from other countries in the world. It turns out that the range between $25 \%$ and $33 \%$ is comparatively high by international standards, with Indonesia's level of vote buying being the third largest in the world (at least as measured in surveys within the last decade). As vote buying is illegal in most countries, including Indonesia, it is plausible to suspect that respondents directly asked about such exchanges are reluctant to provide truthful answers. However, despite this presumed desirability bias, my findings show that the list-experiment and the straightforward survey questions result in consistent estimates of the aggregate levels of vote buying. The chapter discusses this question extensively.

Finally, although this study puts greater weight on vote buying in national parliamentary elections, it also offers new insights into the underexplored nature of such practices in different election settings. In the last part of this chapter, I present historical survey data, owned by my home institutions (LSI and Indikator Politik Indonesia), to identify interregional variation in levels of vote buying in executive elections at the local level. This chapter concludes that vote buying isn't only widespread during national legislative elections, but that it has also become a central feature of local executive elections, where the prize is the position of district head, mayor, or governor.

\subsection{Dimensions and Measures}

To operationalise vote buying as the dependent variable of this study, I created a series of questions about this individualised form of patronage distribution and asked subjects to respond on a various point Likert-type scale to capture attitudes and opinions with a range of answer choices. Given that vote buying is typically associated with negative stigma and thus is associated with social desirability bias, my research follows the methods developed by Brusco and her collaborators (2004: 69) to approach the targeted issue from several different directions. In the postelection survey (the one conducted from 22 to 26 April 2014), the ques- 
tions used seven measures of vote buying with different degrees of directness. This was done in the expectation that the response to any single question wouldn't provide a completely accurate picture of such exchanges. Further, I categorised these seven measures into two dimensions: vote-buying operations in the nationwide legislative elections and vote-buying attempts in the national and local executive elections.

In the survey, the dimension of vote buying in the parliamentary elections consists of four measures. The first is a four-point scale of all experiences with vote buying in legislative elections, without concretely mentioning the 2014 elections in the question (hereafter I referred to this a four-point scale of all vote-buying experience in legislative elections). The question asked: "During the last couple of years, related to the legislative election campaign of national parliamentary (DPR) candidates, how often have candidates or success team members offered you food, household items, and/or other goods in order to influence your vote in the election?" I asked respondents to respond on a four-point Likert-type scale (very often, quite often, rarely, and never), which I then recoded into two categories (very often, quite often, and rarely $=1$, rare and never $=0$ ). I worded the question in this way to gather all experiences of vote buying, including in the currently ongoing campaign. The strategy of not explicitly mentioning the date was intended to capture greater vote-buying reports. Given the survey was conducted when the election had just been held, I wanted to avoid making respondents feel they were being 'interrogated' on what they had just done in the 2014 election, remembering the vote buying is actually illegal in Indonesia. In addition, as noted above, this measure used a four-point scale to increase variation in this variable of interest and was expected to collect greater vote-buying reports than a simple ‘yes-no' question.

Similarly, my second measure of vote buying in legislative elections didn't concretely mention the 2014 election. The prompt was as follows: "These situations sometimes occur during every election in Indonesia. Have you ever experienced these situations below?" The relevant prompt was "Being offered money or goods in order to vote for a certain political party/DPR candidate." The possible responses were 'no,' 'yes, only once or twice,' to 'yes, several times,' and they were recoded to be a two-point scale (yes, only once/twice and yes, several times $=1$, no $=0$ ). The main difference to the question above is that while the first measure used a fourpoint scale, the second used a three-point scale of vote-buying experience (hereafter referred to as a three-point scale of all vote-buying experience in 
legislative elections). We should expect a different outcome since different response options may generate different results. Additionally, the second measure was mixed with a number of other exposures to vote-buying offers in the different election settings that voters could point to, as will be discussed later.

The last two measures of vote buying in legislative elections are on a two-point scale, comprising a pair of questions that explicitly asked about these practices in the 2014 legislative elections. A key difference to the questions above is that respondents might have felt compelled to provide misleading answers in response to questions that directly asked about vote buying in 2014, because this event was still fresh in voters' minds when the post-election survey was conducted and the questions were more specific. Though the question is appealing because it asks directly about the level of vote buying in 2014, it also might drive some respondents to respond in ways that don't reflect their actual behaviour. The question doesn't allow respondents to disguise their answers in terms of past election events. Further, these last two measures are dichotomous scales that are different from the questions above, being a 'yes-no' question which provides a clearer, binary response, but in which bias is more likely.

In this study, the yes-no questions that explicitly mentioned the 2014 elections asked about individual and neighbourhood vote-buying rates. Hence, the third measure inquired about vote buying directed at respondents in 2014 (hereafter referred to as a two-point scale of individual vote buying in the 2014 legislative election). The question reads: "During the run-up to the April 9th 2014 legislative election, did candidates or success team members offer you money, food, household items, and/or other goods (excluding propaganda hats, shirts, and posters)?" The fourth focuses on vote-buying offers witnessed by respondents in their neighbourhood (hereafter referred to as a two-point scale of neighbourhood vote buying in the 2014 elections). The question asked: "During the runup to the April 9th 2014 election, did you observe candidates or success team members offering people in your neighbourhood money, food, household items, and/or other goods (excluding propaganda hats, shirts, and posters)?" These yes-no questions were recoded to scale from 0 (indicating those who responded negatively to both such offers in 2014) to 1 (indicating those who responded positively to both questions). ${ }^{3}$

\footnotetext{
${ }^{3}$ To measure vote buying, I prefer to use 'being offered' rather than 'received' material benefits. Of course, we cannot determine whether voters actually accepted electoral bribes.
} 
Meanwhile, three questions focused on vote-buying attempts in national and sub-national executive elections, as a comparison with the above second measure of general vote-buying experiences in legislative elections. These measures of vote buying in the executive elections are on a three-point scale. The first question reads: "Have you ever experienced being offered money or goods in order to vote for certain presidential/ vice presidential candidates?" (hereafter referred to as a three-point scale of vote buying in presidential elections). The second question asks: "Have you ever experienced being offered money or goods in order to vote for a certain gubernatorial candidate?" (hereafter referred to as a three-point scale of vote buying in governor elections). The third question was: "Have you ever experienced being offered money or goods in order to vote for a certain regent/mayoral candidate?" (hereafter referred to as a three-point scale of vote buying in regency elections). In each case, possible responses were 'no,' 'yes, only once/twice,' and 'yes, several times.' These answers were subsequently recoded to be positioned on a two-point scale ('yes, only once/twice' and 'yes, several times' $=1$, 'no' $=0$ ).

In my analysis of the data, I combined those seven measures described above into an aggregate index of vote buying. As indicated above, to facilitate substantive interpretation of these findings, I recoded each of the vote-buying items from their original scale into dichotomous scales that took a value of 1 if the respondent was exposed to vote-buying attempts or experienced being offered such electoral bribes.

\subsection{How Prevalent Is Vote Buying?}

How widespread is vote buying in Indonesia judged from the measures I have chosen? In this section, I present the main descriptive results of my findings on vote buying, divided into two dimensions: legislative elections and executive elections.

To begin, I demonstrate the findings based on the first dimension of vote buying generated from responses to a battery of four questions that asked about respondents' experiences of vote-buying attempts in legislative elections. Using a four-point scale, as explained above, responses to

But such a question, as Jensen and Justesen (2014: 224) argued, allows us to measure which voters political machines tend to target. By using the word 'being offered,' I intended to avoid social desirability biases that may occur when asking questions about respondents' own behaviour. 
the first question suggest that $33.1 \%$ of respondents reported that they had been offered electoral incentives 'very often,' 'quite often,' or 'rarely.' Although a substantial proportion of the sample (58\%) reported having not been targeted at all, around one-third of the respondents admitting such an experience is a relatively high result (see international comparisons in Sect. 2.4 below), suggesting that such practices have become a conventional strategy in electoral campaigning in Indonesia.

The second measure of vote buying in parliamentary elections produced similar results. Using a three-point continuous scale, this indicated that $29 \%$ of respondents reported being offered cash or goods 'once or twice' or 'several times' during legislative elections. Using similar wording, surveys taken between 2009 and 2014 showed an increase in the rate of vote-buying offers during legislative elections. ${ }^{4}$ In the 2009 legislative elections, only $11.2 \%$ of respondents admitted being targeted for vote buying. The incidence increased in December 2013 (several months before the 2014 legislative elections) to $20.6 \%$ before rising again to $29 \%$ in April 2014 (Fig. 2.1).

Likewise, a descriptive overview of the third and the fourth measures of vote buying in legislative elections, which point to direct individual and neighbourhood vote buying in the 2014 legislative elections, result in consistent findings. Using a dichotomous scale, overall, 25\% admitted having been personally targeted by such exchanges during the 2014 campaigns (Fig. 2.2). The fourth measure, the neighbourhood measure, showed a higher result of $28.9 \%$ (Fig. 2.2).

Although the difference between the various measures is relatively small, ranging from $25 \%$ to $33 \%$ (see the first four rows of Table 2.1 ), one might question about the reasons for these differing results. One probable explanation is that different survey response scales may result in different responses. As noted earlier, individual vote buying in the 2014 legislative election was framed in a straightforward question, asking for a yes-no response, while the first question on overall vote buying in legislative elections was on a four-point Likert-type scale in which those who responded affirmatively ('very often,' 'quite often,' and 'rarely') were categorised into

\footnotetext{
${ }^{4}$ Some of the April 2009 survey findings were reported at the LSI official website (http:// www.lsi.or.id/riset/370/Diskusi\%20LSI\%20Kualitas\%20Pemilu\%202009). But the data cited in this study weren't included in the report and were processed for purposes of this analysis. Similarly, the data quoted from the SMRC 2013 survey were initially not included in that organisation's official report, but I was able to analyse them for this study.
} 


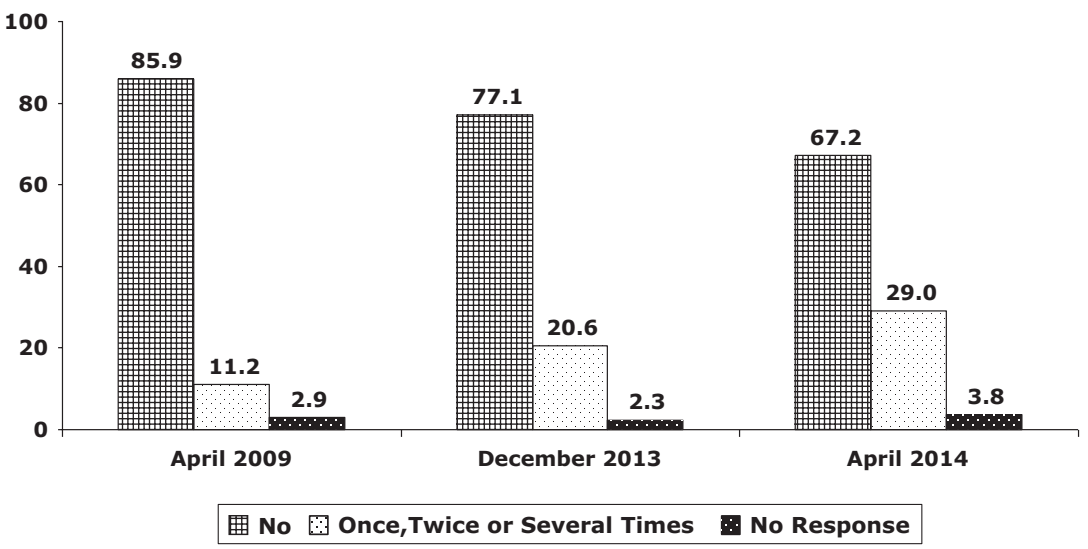

Fig. 2.1 Increasing rates of being targeted for vote buying, 2009-2014 (\%). Source: The April 2009 data was drawn from LSI's survey, the December 2013 data was taken from SMRC's survey, and the April 2014 numbers were drawn from my post-election survey

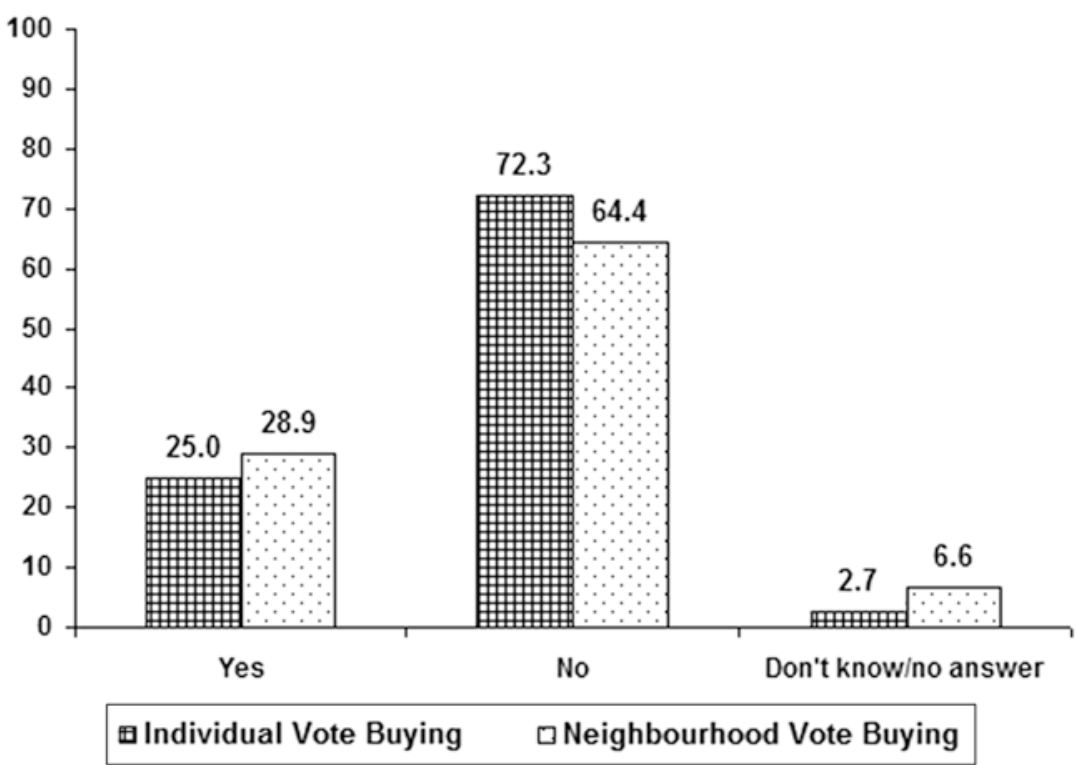

Fig. 2.2 Individual and neighbourhood vote buying in 2014 (\%). Source: $\mathrm{My}$ post-election survey, 22-26 April 2014 
Table 2.1 Relative frequency of responses to various measures of vote buying

\begin{tabular}{|c|c|c|}
\hline Election types & Variable name & $\begin{array}{l}\text { \% 'yes' in } \\
\text { total sample }\end{array}$ \\
\hline \multirow[t]{4}{*}{ Legislative elections } & $\begin{array}{l}\text { 1. A four-point scale of all vote-buying } \\
\text { experience in legislative elections }\end{array}$ & 33.1 \\
\hline & $\begin{array}{l}\text { 2. A three-point scale of all vote-buying } \\
\text { experience in legislative elections }\end{array}$ & 29 \\
\hline & $\begin{array}{l}\text { 3. A two-point scale of individual vote buying } \\
\text { in the } 2014 \text { legislative election }\end{array}$ & 25 \\
\hline & $\begin{array}{l}\text { 4. A two-point scale of neighbourhood vote } \\
\text { buying in the } 2014 \text { legislative election }\end{array}$ & 28.9 \\
\hline \multirow[t]{3}{*}{$\begin{array}{l}\text { National and local } \\
\text { executive elections }\end{array}$} & $\begin{array}{l}\text { 1. A three-point scale of vote buying in the } \\
\text { presidential elections }\end{array}$ & 8.1 \\
\hline & $\begin{array}{l}\text { 2. A three-point scale of vote buying in the } \\
\text { gubernatorial elections }\end{array}$ & 11.3 \\
\hline & $\begin{array}{l}\text { 3. A three-point scale of vote buying in the } \\
\text { district/mayoral elections }\end{array}$ & 13.6 \\
\hline
\end{tabular}

one category as recipients of vote-buying offers. Similarly, the second question which asked all vote-buying experiences was on a three-point scale, providing an option for respondents to report rarity (i.e. 'once or twice') regarding the frequency of being offered vote buying. Perhaps, these greater ranges of responses captured more experiences than the sharply dichotomous scale. But why did the two-point scale used for neighbourhood estimates also result in higher numbers? As Kramon (2013: 70) points out, the neighbourhood measure is less obtrusive than direct, individual measures, because it asks respondents about others' actions. Another reason that neighbourhood vote-buying totals might be larger than selfreported vote-buying totals is that if such practice is open and common, then a single act of vote buying may be observed by several individuals.

Another possible interpretation is that asking about general votebuying experiences without specifically mentioning the 2014 elections would likely generate higher positive answers than questions that concretely point to 2014 . As noted above, mentioning the concrete event can make a psychological difference in that voters may feel pressured to provide truthful answers in response to sensitive questions about a recent act which, in a context like Indonesia, is unlawful. Again, given the timing of the survey, even when posed a question on vote buying that didn't concretely mention 2014, respondents would have included their 2014 
experience in their answer. In fact, it was probably their main reference point. In short, mention of the 2014 elections apparently biased the responses of some respondents who were reluctant to report their recent illicit behaviours.

However, as will be explained in the following section, the results of the list-experiment, which is an increasingly influential technique aimed to minimise response bias in survey questions, show that the estimated percentage of people receiving money or gifts was around $27.4 \%$. Thus, the $25 \%$ of those who experienced vote-buying offers based on the estimate from a dichotomous scale of the vote-buying experience in the 2014 election sounds about right. However, in order to give a sound estimate that reflects a number of different measures, this study suggests that between a quarter and a third of respondents reported having been targeted for vote buying in nationwide legislative elections.

Considering that the percentage difference in the final results between the first-placed and second-placed parties, PDI-P and Golkar, was only $4.2 \%$, this incidence level of vote buying is significant. Moreover, the percentage difference between PDI-P in the first place and Hanura in the tenth place was just $13.69 \%$-well below the vote-buying levels (The Election Commission [KPU], 2014). And as I will show later, the margin of victory for individual candidates was considerably smaller than the margin between parties, making the prevalence of vote buying even more consequential.

Compared to the pre-election survey carried out in March 2014, which captured only half the campaign period, vote-buying incidents increased significantly from $10.7 \%$. This increase suggests that vote buying was more concentrated in the days or hours before election day, or on election day itself. In the Indonesian context, this phenomenon is popularly known as serangan fajar (dawn attack), a term that reflects the fact that material benefits (especially cash) to compensate for votes are sometimes distributed just after the dawn prayer on voting day. Candidates and brokers assume that the closer to voting day they hand things out, the more effective vote buying is in shaping electoral behaviour. These issues, however, aren't unique to Indonesia. The pace of vote buying accelerates as the election date approaches in other countries too, such as in Taiwan (Wang and Kurzman, 2007) or the Philippines (Pulse Asia, 2013).

In order to provide a complete picture of vote-buying practices, those who reported having been offered benefits in the 2014 legislative elections were also asked to name the party or the party of the candidate involved 
in the transaction. Respondents were allowed to mention more than one party, because they might have been approached by candidates from different political parties (see Chap. 7). In their answers, respondents identified all political parties which ran in the 2014 elections, with varying degrees of involvement. This survey finding corresponds with my qualitative observations. "No party was innocent of vote trading. Even candidates from Islamic parties engaged in such practices," said a one-time national parliament member. "I dare you," he continued, "cut off my finger if there is a single MP in Indonesia today who gets elected without buying votes!" (Interview, 20 April 2014). Although vote buying was also common among Islamic parties, the big four vote buyers were non-Islamic in character: of voters who admitted being offered money or a gift, $32.2 \%$ mentioned having received such offers from candidates from Golkar, followed by PDI-P (26.5\%), Gerindra (25\%), and the Democratic Party (18.4\%). Meanwhile, the most common item offered to voters was money (75.5\% of all reported attempts), food products (12.8\%) such as rice, sugar, and noodles, and household items (11.4\%).

As noted earlier, the first three measures consisted of straightforward survey questions about whether individuals encountered offers of material rewards in return for their votes. The fourth measure, however, asked respondents to report whether they observed other people in their neighbourhood or village experiencing such encounters in 2014. Arguably, this question may be less accurate since it is based on perceptions, which can be accurate or not. Nevertheless, asking questions about illegal practices by treating respondents as an 'observer' is less vulnerable to response bias because the question doesn't require respondents to report on their own potentially illicit behaviour (Kramon, 2013: 70). The results of this fourth measure showed that $28.9 \%$ of respondents had witnessed or knew that such practices occurred in areas where they lived (see Fig. 2.2). These figures are only slightly larger than responses to the direct question (the third measure), in which $25 \%$ of respondents admitted being offered a vote-buying exchange in the 2014 election. The gap between the two is within the margin of error used in this survey and is therefore statistically insignificant.

The results from both the neighbourhood and individual measures are also consistent in terms of the perpetrators and items of vote buying. Among those who reported that their neighbourhood was being targeted, Golkar again topped the list of most frequently mentioned vote buyers (35.5\%), followed by PDI-P (30.6\%), Gerindra (26.8\%), and the Democratic Party $(20.6 \%)$, repeating the order in the individual vote-buying measure. 
Similarly, as among respondents who individually observed vote buying, all political parties were mentioned by at least some respondents as engaging in vote-buying efforts in the neighbourhood measure. Money, food, and household items were also again the most frequent goods reported as being distributed in exchange for votes. Of those who witnessed their neighbourhood as having been targeted, $78.9 \%$ reported that people in their locations were given cash handouts, followed by food $(12.8 \%)$, household goods (11.4\%), and other items (14.8\%). Note that the respondents were allowed to provide multiple answers.

In order to make a direct comparison of different election seasons, my 2014 voter survey also asked a number of questions about the 2009 legislative election, using wording nearly identical to the individual and neighbourhood items. The results confirm my earlier finding (based on 2009 and 2013 surveys) that vote buying was more pervasive in 2014 than in 2009. Only $10.1 \%$ of respondents reported having individually been the target of such handouts in 2009. In terms of the background of vote buyers, the vote market was again dominated by non-Islamic parties such as Golkar, PDI-P, and Democratic Party. The most common items distributed to voters in 2009 were also cash payments, foodstuffs, and household goods. When asked about the extent to which vote buying in 2009 happened in their neighbourhood, though statistically insignificant, affirmative responses to this inquiry were a little bit higher (12.9\%) than responses to the questions asked about the individual experiences of survey respondents (10.1\%).

Having discussed vote buying in the legislative elections, we are now in a position to explore the second dimension of this form of patronage exchange: vote buying in executive elections at the national and local level. Figure 2.3 demonstrates survey estimates of the proportion of voters who experienced being offered electoral incentives in such elections. In terms of presidential elections, my survey in April 2014 (around three months before the presidential elections $)^{5}$ showed that only $8.1 \%$ of those surveyed reported having received vote-buying offers either 'once or twice' or 'several times.' In addition, according to the same April 2014 survey, vote-buying reports in the regency and gubernatorial elections were relatively similar, standing at $13.6 \%$ and $11.3 \%$, respectively. It is plausible to

\footnotetext{
${ }^{5}$ Unfortunately, this question wasn't asked in our surveys that were closer to the 2014 presidential elections, or after it.

${ }^{6}$ Although this figure was much lower than in legislative elections, based on the LSI postelection survey in April 2009, there has been a significant increase compared with 2009 when only $3.2 \%$ reported an acquaintance being offered such incentives.
} 


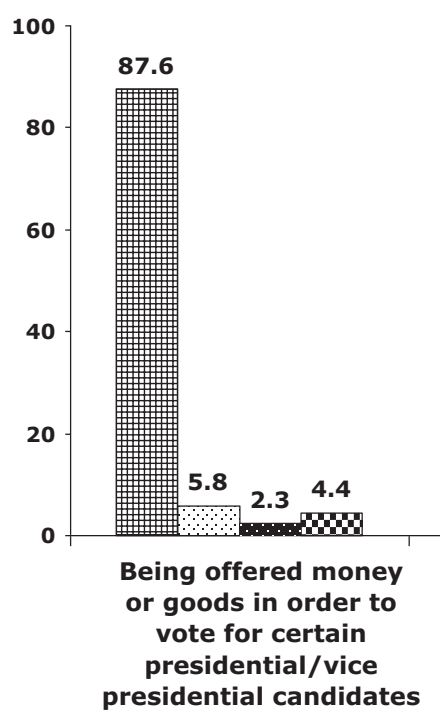

84.4

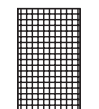

82.0
Being offered money or goods in order to vote for a certain gubernatorial candidate

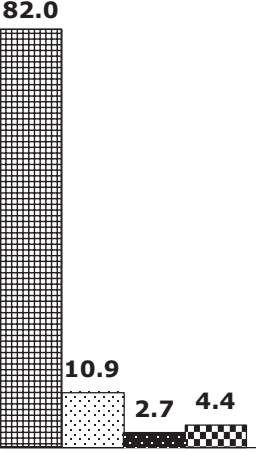

团 No Yes, once or twice

Yes, several times

Being offered money or goods in order to vote for a certain regent/mayoral candidate

Fig. 2.3 Vote-buying offers at the national and local executive elections (\%). Source: My post-election survey, 22-26 April 2014

conclude, therefore, that vote-buying attempts were more prevalent during parliamentary elections relative to presidential and sub-national executive elections (I will present additional data from an historical dataset on sub-national elections that confirms this finding at the end of this chapter).

These results are in line with the research of other scholars who argue that constituency size matters in explaining the different levels of vote buying in multiple election settings. Stokes (2007: 86), for example, argues that vote buying decreases as constituency size grows, and vice versa. When the constituency is very large, as in presidential elections, it is difficult for politicians to buy the amount of votes necessary to make a nationwide difference. Presidential candidates instead rely more on the national media in attempting to reach out to a broad audience. By contrast, in direct local elections in smaller rural districts (kabupaten) and urban municipalities (kota), the cost of vote buying is less expensive and the practical challenges less daunting, thereby creating an incentive for candidates to engage in such practices. In national 
parliamentary elections-which comprise the national-level DPR, or People's Legislative Council; 34 province-level DPRDs (Regional Legislative Councils); and DPRDs in 508 kabupaten/kota-vote buying is also widespread because the various electoral constituencies are manageable in size (being concomitantly smaller than the region-wide electorates in the relevant executive government head elections), and because candidates at different levels can coordinate their vote-buying efforts. Aspinall and Sukmadjati highlight the point that since "kabupaten and kota electoral districts are nested inside provincial electoral districts, which are in turn nested inside national electoral districts.... it is relatively easy for candidates running at different levels to coordinate their efforts in the hope of maximising their individual chances of success" (2016: 14-15). ${ }^{7}$ This, in turn, increases the likelihood of vote buying in the legislative elections (see Chap. 6).

Another plausible explanation for why vote-buying efforts are more common in legislative elections is that the number of candidates running for national, provincial, and district parliaments is much larger than that of competitors in presidential and regional head elections (see Mujani et al., 2012: 98). The number of seats contested in the 2014 legislative elections was 19,699, which were situated in the national, provincial, and district legislative assemblies. A total of 6608 candidates ran for the 560 seats in the DPR, around 10,000 candidates competed at the provincial level, and hundreds of thousands of candidates stood at kabupaten/kota level. In a single electoral district, there could be as many as 144 candidates competing at each level of legislative elections. In addition to the DPR and DPRDs, candidates also competed for the 136-seat Regional Representative Council (DPD). ${ }^{8}$ In the 2014 presidential elections, by contrast, there were only two presidential and vice presidential candidates in the race. Similarly, since 2005 (when direct local elections were introduced), there have never been more than 11 pairs of candidates in such a contest. Thus, the relatively limited number of candidates running for either presidential or local elections reduces the incentive for them to engage in vote buying if compared to their legislative counterparts running in massive, more competitive elections.

\footnotetext{
${ }^{7}$ The exception to this general rule is Java where national and provincial electoral districts share the same boundaries. For further discussion, see Aspinall and Sukmajati (2016).

${ }^{8}$ Detik.com, "200 Ribu Caleg yang Berebut 19 Ribu Kursi di 2014," 9 January 2014, available at https://news.detik.com/berita/2462640/200-ribu-caleg-yang-berebut-19ribu-kursi-di-2014, accessed 3 March 2016.
} 


\subsection{The Vote-Buying Index}

Having discussed the descriptive results, I can now develop an additive index of 'vote buying,' based on responses to the battery of seven questions summarised in the preceding section. The Cronbach's alpha coefficient for the variables that make up the vote-buying index is 0.841 , meaning that the variables have a high degree of internal consistency, and this suggests that the items in the test are highly correlated. As noted above, I differentiate vote buying into two dimensions: vote buying in parliamentary elections and vote buying in the presidential and local executive elections.

In order to establish that vote buying comprises these two dimensions, I use a confirmatory factor analysis. As shown in Table 2.2, the variables that make up the vote-buying index yield two components: (1) the four items related to vote buying in parliamentary elections constitute a single factor, and (2) the three items related to vote buying in the national and local executive elections produce another dimension. In other words, the variables that relate to vote-buying experiences in executive elections are

Table 2.2 Factor analysis of vote buying (Rotation method: Varimax with Kaiser normalisation)

\begin{tabular}{lcc}
\hline & \multicolumn{2}{c}{ Dimension } \\
\cline { 2 - 3 } & $\begin{array}{l}\text { Vote buying in the } \\
\text { legislative elections }\end{array}$ & $\begin{array}{c}\text { Vote buying in the } \\
\text { executive elections }\end{array}$ \\
\hline $\begin{array}{l}\text { A four-point scale of all vote-buying } \\
\text { experience in legislative elections }\end{array}$ & 0.745 & 0.216 \\
$\begin{array}{l}\text { A three-point scale of all vote-buying } \\
\text { experience in legislative elections }\end{array}$ & 0.792 & 0.368 \\
$\begin{array}{l}\text { A three-point scale of vote buying in the } \\
\text { presidential elections }\end{array}$ & 0.216 & 0.650 \\
$\begin{array}{l}\text { A three-point scale of vote buying in the } \\
\text { gubernatorial elections }\end{array}$ & 0.208 & 0.826 \\
$\begin{array}{l}\text { A three-point scale of vote buying in the } \\
\text { regency/mayoral elections } \\
\text { A two-point scale of individual vote buying } \\
\text { in the 2014 legislative election }\end{array}$ & 0.256 & 0.200 \\
$\begin{array}{l}\text { A two-point scale of neighbourhood vote } \\
\text { buying in the 2014 legislative election }\end{array}$ & 0.744 & 0.151 \\
\hline
\end{tabular}

Extraction method: Maximum likelihood 
empirically distinct from those that for legislative elections. This factor analysis reinforces the notion that the categorisation of vote buying based on the two distinct dimensions above is valid.

Hence, throughout this study, I apply the index of vote buying in statistical equations, including cross-tabulation, bivariate and multivariate analyses. I start this exercise by index-scoring the two dimensions of vote buying. First, the mean score of vote buying in parliamentary elections derived from the four measures mentioned above-which vary from 0 (didn't engage) to 1 (engaged) was 0.3145 . Importantly, the bivariate statistical analysis reveals the correlation pattern between all vote-buying variables in the legislative elections (Table 2.3).

Second, the overall score of vote-buying offers in national and local executive elections-normalised to vary between 0 (didn't engage) and 1 (engaged)—was 'only' 0.1121 . I also conducted a bivariate test with a Pearson correlation to look at the relationship between all three primary variables that constitute the dimension of vote buying in elections for presidential and regional heads (Table 2.4). Based on this bivariate test, the relationship between vote buying in presidential elections, vote-buying offers in the gubernatorial elections, and vote buying in the regency/mayoral elections is substantial and statistically significant.

Table 2.3 Correlation between vote-buying variables in parliamentary elections

\begin{tabular}{lllll}
\hline & $\begin{array}{l}\text { Four-point } \\
\text { scale of all } \\
\text { vote-buying } \\
\text { experience }\end{array}$ & $\begin{array}{l}\text { Three-point } \\
\text { scale of all } \\
\text { vote-buying } \\
\text { experience }\end{array}$ & $\begin{array}{l}\text { Two-point scale } \\
\text { of individual } \\
\text { vote buying in } \\
2014\end{array}$ & $\begin{array}{l}\text { Two-point scale of } \\
\text { neighbourhood vote } \\
\text { buying in 2014 }\end{array}$ \\
\hline $\begin{array}{l}\text { Four-point scale of } \\
\text { all vote-buying } \\
\text { experience }\end{array}$ & 1 & $0.698^{* \star *}$ & $0.551^{* * *}$ & $0.420^{* * *}$ \\
$\begin{array}{l}\text { Three-point scale of } \\
\text { all vote-buying } \\
\text { experience }\end{array}$ & $0.698^{* * *}$ & 1 & & $0.474^{* * *}$ \\
$\begin{array}{l}\text { Two-point scale of } \\
\text { individual vote } \\
\text { buying in } 2014\end{array}$ & $0.551^{* * *}$ & $0.643^{* * *}$ & 1 & $0.565^{* \star *}$ \\
$\begin{array}{l}\text { Two-point scale of } \\
\text { neighbourhood vote } \\
\text { buying in } 2014\end{array}$ & $0.420^{* * *}$ & $0.474^{* * *}$ & $0.565^{* * *}$ & 1 \\
\hline
\end{tabular}

${ }^{* * *}$ Correlation is significant at the 0.001 level (two-tailed) 
Table 2.4 Correlation between vote-buying variables in the national and local executive elections

\begin{tabular}{|c|c|c|c|}
\hline & $\begin{array}{l}\text { Vote buying in } \\
\text { presidential elections }\end{array}$ & $\begin{array}{l}\text { Vote buying in } \\
\text { governor elections }\end{array}$ & $\begin{array}{l}\text { Vote buying in } \\
\text { regency elections }\end{array}$ \\
\hline $\begin{array}{l}\text { Vote buying in } \\
\text { presidential elections }\end{array}$ & 1 & $0.613^{* * *}$ & $0.568^{\star \star \star}$ \\
\hline $\begin{array}{l}\text { Vote buying in } \\
\text { governor elections }\end{array}$ & $0.613^{* * *}$ & 1 & $0.708^{\star \star \star}$ \\
\hline $\begin{array}{l}\text { Vote buying in regency } \\
\text { elections }\end{array}$ & $0.568^{* \star *}$ & $0.708^{* * *}$ & 1 \\
\hline
\end{tabular}

${ }^{* * *}$ Correlation is significant at the 0.001 level (two-tailed)

Recall again that the overall score of the vote-buying index is an additive scale based on responses to a battery of seven measures that make up the two dimensions of vote buying described above. The scale runs from 0 (not exposed to vote buying) to 1 (exposed). The average of the votebuying index is relatively high, with a score of 0.2103 . There is, however, substantial component variation. At the low end, people who were exposed to vote-buying attempts during an election for national and regional government heads only make up a modest proportion of the total electorate, with a score of 0.1121 . In particular, people were less likely to have experience of vote buying in presidential elections, with a score of 0.0841 . At the top end, people were more likely to be targeted for vote buying in parliamentary elections, with a score of 0.3145 . Therefore, as with the above descriptive analysis of the measures, it is safe to conclude from the index that among the two different election settings, vote buying is more common during parliamentary elections than during national and local executive elections. The reasons behind these different rates of vote buying have been already explained above: the effect of constituency size and the differences in competitiveness between these two types of elections.

Although the average of vote-buying occurrence in parliamentary elections is higher than in executive elections, the bivariate model suggests that these two dimensions of vote buying have a positive correlation and are statistically significant in the expected direction (Table 2.5). It can be inferred, therefore, that those who have traditionally benefited from clientelist exchanges in parliamentary elections are more likely to be targeted for vote buying in the national and sub-national executive elections as well. The correlation also exists the other way around. Those 
Table 2.5 Correlation (Pearson's $r$ ) between vote-buying variables in the parliamentary elections and executive elections

\begin{tabular}{lll}
\hline & $\begin{array}{l}\text { Vote buying in } \\
\text { legislative elections }\end{array}$ & $\begin{array}{l}\text { Vote buying in the presidential } \\
\text { and local executive elections }\end{array}$ \\
\hline $\begin{array}{l}\text { Vote buying in legislative } \\
\text { elections }\end{array}$ & 1 & $0.479^{* * *}$ \\
$\begin{array}{l}\text { Vote buying in the presidential } \\
\text { and local executive elections }\end{array}$ & $0.479^{* * *}$ & 1 \\
\hline
\end{tabular}

${ }^{* * *}$ Correlation is significant at the 0.001 level (two-tailed)

being exposed to vote-buying attempts in presidential and regional head elections are more likely to be the target of such exchanges in legislative elections.

What does this correlation suggest? Concretely, it implies that political machines are more likely over time to direct their vote-buying efforts more heavily towards a group of voters for whom vote buying is a more common, repeat experience. This finding is in line with the concept of base voters, according to which loyalist voters are locked into long-term political relationships with parties or politicians based on patronage ties (see Chap. 5). In many cases, political agents (or brokers) assume that such voters are more responsive to clientelist exchanges, which in turn triggers an increase in vote buying targeting this group. Furthermore, as I elaborate in more detail in the following chapters, the logic of various elements of Indonesia's institutional framework, such as optional voting, open-list proportional system, and ballot secrecy, create strong incentives for candidates to target such voters because they are thought of as being more reciprocal, and thus a more predictable source of votes.

\subsection{InTERNATIONAL COMPARABILITY}

I have explained at length the ubiquity of vote buying in Indonesian elections. To put these numbers into perspective, it is important to compare the rate of self-reported vote buying, especially in parliamentary elections, with rates from other countries in the world. As indicated earlier, I used a number of questions in my surveys that are partially derived from and are comparable to similar questions that have been asked elsewhere. This allows me to make direct comparisons with vote-buying levels in other countries, as presented in Table 2.6. 
Table 2.6 Estimated proportion of direct vote buying by country

\begin{tabular}{|c|c|c|c|c|c|c|c|c|}
\hline Country & $\%$ & $N$ & Country & $\%$ & $N$ & Country & $\%$ & $N$ \\
\hline Uganda 2012 & 41 & 2400 & Mexico 2010 & 17 & 1562 & $\begin{array}{l}\text { Cote d'Ivoire } \\
2013\end{array}$ & 7 & 1200 \\
\hline Benin 2012 & 37 & 1200 & $\begin{array}{l}\text { Paraguay } \\
2010\end{array}$ & 16 & 1502 & Ghana 2012 & 7 & 2400 \\
\hline $\begin{array}{l}\text { Indonesia } \\
2014^{a}\end{array}$ & 33 & 1210 & Burundi 2012 & 16 & 1199 & Malaysia 2013 & 7 & NA \\
\hline Kenya 2011 & 32 & 2399 & $\begin{array}{l}\text { Colombia } \\
2010\end{array}$ & 15 & 1506 & Nicaragua 2010 & 6 & 1540 \\
\hline Liberia 2012 & 28 & 1199 & $\begin{array}{l}\text { Cameroon } \\
2013\end{array}$ & 14 & 1200 & Botswana 2012 & 6 & 1200 \\
\hline Swaziland 2013 & 27 & 1200 & Malawi 2012 & 14 & 2407 & Cape Verde 2011 & 6 & 1208 \\
\hline Mali 2012 & 26 & 1200 & $\begin{array}{l}\text { Tanzania } \\
2012\end{array}$ & 14 & 2400 & Jamaica 2010 & 6 & 1504 \\
\hline Niger 2013 & 24 & 1200 & $\begin{array}{l}\text { Guatemala } \\
2010\end{array}$ & 14 & 1504 & $\begin{array}{l}\text { South Africa } \\
2011\end{array}$ & 6 & 2399 \\
\hline $\begin{array}{l}\text { Sierra Leone } \\
2012\end{array}$ & 23 & 1190 & Brazil 2010 & 13 & 2482 & Guyana 2010 & 6 & 1540 \\
\hline $\begin{array}{l}\text { Dominican Rep } \\
2010\end{array}$ & 22 & 1500 & $\begin{array}{l}\text { Madagascar } \\
2013\end{array}$ & 13 & 1200 & Uruguay 2010 & 6 & 1500 \\
\hline $\begin{array}{l}\text { Burkina Faso } \\
2012\end{array}$ & 22 & 1200 & Zambia 2012 & 13 & 1200 & Chile 2010 & 6 & 1965 \\
\hline Morocco 2013 & 22 & 1200 & Peru 2010 & 12 & 1500 & $\begin{array}{l}\text { Trinidad \& } \\
\text { Tobago } 2010\end{array}$ & 5 & 1503 \\
\hline $\begin{array}{l}\text { Philippines } \\
2013\end{array}$ & 22 & 1200 & $\begin{array}{l}\text { Venezuela } \\
2010\end{array}$ & 12 & 1500 & $\begin{array}{l}\text { Mozambique } \\
2012\end{array}$ & 5 & 2400 \\
\hline Egypt 2013 & 20 & 1200 & Guinea 2013 & 11 & 1200 & Honduras 2009 & 4 & 1005 \\
\hline Nigeria 2012 & 19 & 2400 & Senegal 2013 & 11 & 1200 & Algeria 2013 & 3 & 1206 \\
\hline $\begin{array}{l}\text { Zimbabwe } \\
2012\end{array}$ & 19 & 2400 & $\begin{array}{l}\text { El Salvador } \\
2010\end{array}$ & 10 & 1550 & Lesotho 2012 & 2 & 1197 \\
\hline Argentina 2010 & 18 & 1410 & Togo 2012 & 10 & 1200 & Mauritius 2012 & 1 & 1200 \\
\hline Panama 2010 & 18 & 1536 & $\begin{array}{l}\text { Costa Rica } \\
2010\end{array}$ & 9 & 1500 & Tunisia 2013 & 1 & 1200 \\
\hline Belize 2010 & 17 & 1504 & Ecuador 2010 & 8 & 3000 & & & \\
\hline Bolivia 2010 & 17 & 3018 & $\begin{array}{l}\text { Suriname } \\
2010\end{array}$ & 7 & 1516 & Average & 14.22 & \\
\hline
\end{tabular}

Sources: The Latin American Public Opinion Project (LAPOP) Americas Barometer 2010 and the Afrobarometer Round 5, 2011-2012. The data from Malaysia was taken from Meredith Weiss, "General Election 2013 Survey Results" (2013), while the rate of vote buying from the Philippines was taken from Pulse Asia, “On the 2013 Elections: Observations and Select Survey Results" (2013) (The data from Malaysia and Philippines were presented at "Workshop of Money Politics, Patronage and Electoral Dynamics," Yogyakarta, 13-15 December 2013)

${ }^{a}$ Derived from the first measure of all vote-buying experience in legislative elections 
To that end, I use an estimate based on my first measure of all votebuying experience (it will be recalled that this was responses to the question: "During the last couple of years, related to the legislative election campaign of national parliamentary (DPR) candidates, how often have candidates or success team members offered you food, household items, and/or other goods in order to influence your vote in the election?"). This question was similar to questions asked by both LAPOP Americas Barometer and Afrobarometer. The data on vote-buying levels in Latin American and African countries presented in Table 2.6 are all taken from the two polling associations. While the wording of questions varied slightly in some of the studies, the questions were overall congruent. The LAPOP worded the question as follows: "In recent years and thinking about election campaigns, has a candidate or someone from a political party offered you something like a favour, food, or any other benefits or thing in return for your vote?" Respondents could indicate that they 'never,' 'sometimes,' or 'often' have been offered electoral incentives in return for their vote. Responses were coded 'yes,' if they reported 'often' or 'sometimes' having been the target of such practice.

The Afrobarometer asked the following question: "And during the last national election in $[20 \mathrm{xx}]$, how often, if ever, did a candidate or someone from a political party offer you something, like food or a gift or money, in return for your vote?" Respondents responded on a five-point Likert-type scale, with responses ranging from 'never,' 'once or twice,' 'a few times,' 'often,' and 'no experience in the past year.' The main difference is that I used a four-point scale in the first measure, while the LAPOP Americas Barometer and Afrobarometer employed a three-point scale and five-point scale, respectively. In the case of Malaysia and the Philippines, the frequency of vote buying in both countries was based on a dichotomous scale: whether or not respondents had been offered material benefits during the current/most recent elections. ${ }^{9}$

Turning to the comparison of vote-buying levels, Table 2.6 shows that there is a wide variation in the level of self-reported vote-buying transactions across in the continents of Asia, Latin America, and Africa, in surveys taken over the last decade. The average level of vote buying around the world is $14.22 \%$, with some countries scoring well below the global aver-

\footnotetext{
${ }^{9}$ The question reads: "During the run-up to the 2013 elections, did any political party offer you money, food, household items, and/or other goods (excluding propaganda hats, shirts, and posters)?”
} 
age and some significantly above it. Vote-buying intensity is greatest in the cases of Uganda (41\%), Benin (37\%), Indonesia (33\%), Kenya (32\%), Liberia (28\%), Swaziland (27\%), Mali (26\%) and Niger (24\%). Remarkably, the level of vote buying in Indonesia, when we use the higher estimate $(33 \%)$, is more than double the global average.

In contrast, vote-buying incidents were virtually non-existent in Lesotho $(2 \%)$, Mauritius (1\%), and Tunisia (1\%). In general, consistent with the expectations from prior findings, offers of vote buying in many African and Asian countries are reported in higher numbers than in Latin America (Schaffer, 2007). Confirming this pattern, the study of De Jonge (2015) — which analysed survey data from ten elections in eight Latin American countries-also found that vote-buying incidence wasn't as high as in other parts of the world. ${ }^{10}$ In contrast, it is clear that vote buying in Indonesia is comparatively prevalent, and that such practices are central in the country's electoral politics.

\subsection{Little Social Desirability Bias}

Given that these data are entirely based on surveys, we must ask: how valid are estimates of vote buying based on direct individual measures established through polls? As noted above, vote buying is illegal in most countries, including Indonesia, and usually linked to a negative social stigma (Gonzalez-Ocantos et al., 2012; Hicken, 2007). Therefore, some scholars have expressed suspicions that respondents directly asked about such practices are unlikely to report accurate information due to the problem of social desirability (Gallego and Wantchekon, 2012; Corstange, 2012). In order to address this concern, survey-based experiments are suitable instruments to evaluate the credibility of individual survey items and consolidate their overall validity. This is particularly the case for clientelism research, which has attracted renewed scholarly interest in recent years.

In the following, therefore, I present my findings on the estimated proportion of people receiving material benefits for their vote based on a listexperiment, embedded within two nationally representative surveys, conducted before and after the 2014 legislative elections. There were two underlying assumptions for conducting the list-experiment. First, we must assume that respondents give truthful answers to the sensitive item (Blair

\footnotetext{
${ }^{10}$ For my comparative overview, I chose the LAPOP Americas Barometer (2010) datawhich provides a higher aggregate estimate of such incentives in the case of South American countries-because it used a more comparable direct survey item.
} 
and Imai, 2012: 56). Second, we must assume that "the inclusion of a sensitive item has no effect on respondents' answers to control items" (Blair and Imai, 2012: 51). ${ }^{11}$

First of all, the list-experiment participants were divided into four random halves: one control group and three treatment groups. ${ }^{12}$ Interviewers read the same question for each group. Respondents in each group were also provided with a show card for their response choices, which differed by group only in the number of response categories. These items were designed together with the project leaders of 'Money Politics in Southeast Asia,' while considering floor and ceiling effects that must be avoided. ${ }^{13}$ The opening statement in the first list-experiment was the following question:

I am going to read you various activities, and I would like for you to tell me if they have been carried out by candidates or team success members during the run-up to the April 9th 2014 election? Please don't tell me which ones, only how many? (one, two, or three campaign activities)

For the control group, I listed the following campaign activities:

1. They put up campaign posters or signs in your neighbourhood/city.

2. They visited your home.

3. They placed campaign advertisements in television/newspaper/radio.

${ }^{11}$ See also, Eric Kramon, "Vote Buying and Accountability in Democratic Africa," PhD Dissertation at UCLA, 2013.

${ }^{12}$ It must be noted that in the pre-election survey, the sample was only divided into two random halves: a treatment and a control group. Overall, although there is some modification, the list-experiment that this study implemented was largely guided by GonzalezOcantos, Ezequiel, Chad Kiewiet de Jonge, Carlos Meléndez, Javier Osorio and David W. Nickerson, "Vote Buying and Social Desirability Bias: Experimental Evidence from Nicaragua," American Journal of Political Science, Vol. 56 (1), No. 1, January, 2012: pp. 202-217. My experimental survey is also inspired by Kramon (2013) and De Jonge (2015).

${ }^{13}$ The possible presence of floor effects has long been central in the discussion among scholars. Blair and Imai (2012: 49-50) detect that floor effects may appear "if the control questions are so uncontroversial that uniformly negative responses are expected for many respondents." Another possible 'floor effect' may result if respondents fear that answering ' 0 ' reveals their honest (negative) preference (Ibid). There is some debate on this is, because on the other side of the coin, there may be 'ceiling effects' referring to a condition where all of the items would be acceptable to many participants. See Graeme Blair and Kosuke Imai (2012), "Statistical Analysis of List experiments," Political Analysis 20(1), 47-77. 
Among those activities, how many had been carried out by candidates or brokers? Respondents could pick one, two, or three (all of them). I also provided an option for the scenario that 'none' of them had been carried out by candidates and their operatives. Meanwhile, each treatment group, which contained different sensitive issues, was presented a fourth different option, placed in the third response position.

1. They coerced you to vote for them (first treatment group).

2. They gave you a gift or did you a favour (second treatment group).

3. They offered you a job (third treatment group).

Participants were then asked not to mention which items were true for them. They were only required to indicate how many of the items were true for them (see Kramon, 2013). Respondents could choose one, two, three, four, or all of them. Again, there was an optional answer for the scenario that 'none' of them had been carried out by candidates or their operatives. Following Gonzalez-Ocantos and his colleagues (2012) and De Jonge (2015), interviewees weren't asked to tell the field surveyor which particular activities they had experienced so that the surveyor wouldn't realise whether the respondent was reporting the sensitive item (receipt of cash or gifts) or not. The goal was to reduce social desirability bias (De Jonge, 2015).

Having previously shown the descriptive findings of the individual and neighbourhood measures, I now start the analysis and interpretation of the results from the list-experiment. The first column of Table 2.7 is the descriptive analysis to estimate people's experience of receiving handouts during campaigns. Table 2.7 shows the means for each experimental setting, namely one control group and three treatment groups. The list-experiment results found systematic differences in the means, providing a point estimate on the number of people reporting incidents of vote buying and coercion.

Table 2.7 Descriptive analysis

\begin{tabular}{lll}
\hline Treatment & $n$ & Mean \\
\hline Control & 272 & 1.393 \\
Treatment I (coercion) & 263 & 1.574 \\
Treatment II (vote buying) & 283 & 1.668 \\
Treatment III (job offer) & 267 & 1.416 \\
\hline
\end{tabular}


The mean number of three campaign activities that include campaign posters or signs in the neighbourhood, party/candidate/broker visits, and campaign advertisements in television/newspaper/radio, reported by respondents in the control group, is 1.393 . The average number of items indicated by the first treatment group, where subjects had the added option of "being coerced to vote for any political party or candidate," is 1.574. Subsequently, the mean number indicated by the second treatment group, where the subject had the choice of 'receiving money or gifts or favors,' is 1.668. Finally, the average number of items by the third treatment group which provided the additional option of a job offer for voters is only 1.416.

Thus, an estimation of the percentage of people reporting the receipt of electoral incentives can be established by comparing the average number of items indicated by the respondents in each group. Table 2.8 shows the treatment minus control differences. As the average number of items indicated by the control group is 1.393 and the average number of items indicated by the first treatment group is 1.574 , we can conclude that $18.1 \%$ of respondents experienced coercion $(1.574-1.393=0.181$ and $0.181 \times 100=18.1 \%)$. Random assignment assures that the difference is owing to respondents admitting coercion during elections. This number is clearly statistically significant ( sig. $<0.05$ ). Meanwhile, the mean number shown by the second treatment group (vote buying) is 1.668 , producing a result of $1.668-1.393=0.274$ and $0.274 \times 100=27.4 \%$.

Hence, importantly for this study, the estimation of the proportion of respondents receiving electoral incentives according to the list-experiment is $27.4 \%$, much higher than the proportion of those experiencing coercion $(18.1 \%)$. The difference is highly significant (sig. $<0.05)$. By contrast, clientelist exchange that took the form of a job offer to voters isn't statistically significant, with only a $2.2 \%$ difference between the control and

Table 2.8 Estimated percentage of respondents reporting the receipt of vote buying

\begin{tabular}{|c|c|c|c|}
\hline & $\begin{array}{l}\text { Estimated } \\
\%\end{array}$ & $\begin{array}{l}S E \\
(\%)\end{array}$ & Sig. \\
\hline Respondents were coerced to vote (Treatment I - Control) & 18.1 & 7.6 & 0.018 \\
\hline $\begin{array}{l}\text { Respondents were given money or gifts (Treatment } \\
\text { II - Control) }\end{array}$ & 27.4 & 7.5 & 0.000 \\
\hline Respondents were offered a job (Treatment III - Control) & 2.2 & 7.6 & 0.769 \\
\hline
\end{tabular}

Source: This list-experiment was embedded within the post-election survey 22-26 April 2014 
treatment groups. It can be concluded, therefore, that the practice of offering a job in exchange for a vote is rare in Indonesian electoral politics.

Interestingly, the estimated percentage of respondents reporting the receipt of handouts in this April 2014 list-experiment nearly tripled in comparison to a similar survey-based experiment carried out in March 2014, around one month before the election (see Table 2.9). Despite the sample being divided only into two random halves, the procedure of randomisation was exactly the same. In the pre-election survey, I also used a wording that was nearly identical to items employed in the post-election survey-based experiment. Table 2.9 reports the comparison between the results of the list-experiment in pre- and post-election surveys. As explained earlier, the estimated percentage of people receiving money or gifts according to the post-election survey-based experiment was 27.4\%. Meanwhile, the mean number of campaign activities indicated by the control group with only four options in the pre-election experiment was 1.414, whereas the mean in the treatment group, where items had the additional option of picking the scenario of 'receiving money or gifts,' was 1.519. Hence, the intensity of vote buying that occurred about one month prior to the election was only $10.4 \%$ (Treatment - Control, $1.519-1.414=0.104$, and $0.104 \times 100=10.4 \%)$. The results from the pre- and post-election survey-based experiment are all statistically significant $($ sig. $<0.05)$.

The results thus far have found that that the estimates gathered from direct individual measures don't differ much from what is found in the list-experiment. The estimates derived from each method are strikingly similar, suggesting that in Indonesia, direct survey questions about individuals' experience receiving cash handouts aren't subject to response bias.

Table 2.9 Vote buying in both pre- and post-election survey-based experiments

\begin{tabular}{lllll}
\hline \multirow{2}{*}{ Treatment } & \multicolumn{3}{l}{ March 2014 } & \multicolumn{2}{l}{ April 2014 } \\
\cline { 2 - 5 } & $n$ & Mean & $n$ & Mean \\
\hline Control & 556 & 1.414 & 273 & 1.398 \\
Treatment & 561 & 1.519 & 284 & 1.674 \\
Estimated \% reporting the receipt of money or gifts & $10.4 \%$ & & $27.4 \%$ & \\
& & $($ sig. $=0.049)$ & & $($ sig. $=0.000)$ \\
\hline
\end{tabular}

Source: The pre-election survey-based experiment was done during 19-24 March 2014, while the postelection experiment was conducted during 22-26 April 2014 
My finding contrasts with that of Gonzalez-Ocantos and his colleagues (2012), who found substantial bias in a similar survey item asked in Nicaragua. My findings also contrast with those put forward by Corstange (2012) in his study of the 2009 Lebanese parliamentary elections and De Jonge (2015) in the case of the 2009 Honduran election. Both studies suggested that vote buying is found to be much more pervasive if detected via the list-experiment. My study, by contrast, confirms earlier work by Amick (2016: 1), who found that relative to a list-experiment, "direct survey questions to [Indonesian] voters about accepting transfers from campaigns elicits mostly honest responses from respondents."

Accordingly, my findings indicate that the difference between the direct individual and neighbourhood measures and the list-experiment isn't statistically significant. My list-experiment estimates about $27.4 \%$ of respondents actually sold their votes, compared to approximately $25 \%$ of respondents when asked directly about their personal experience of the 2014 elections. In every category of the individual-level questions discussed above, the estimates were statistically similar to those recorded by the list-experiment. Even the neighbourhood measure only gives a slightly higher estimate $(28.9 \%)$ than the list-experiment.

Hence, the direct individual measure is reliable enough to estimate attempts of vote buying. This conclusion is supported by the fact that in the pre-election nationwide survey (March 2014), I found almost exactly the same estimates in the list-experiment and direct measure. In that survey, the list-experiment estimated that approximately $10.4 \%$ of respondents accepted electoral handouts, compared to $10.7 \%$ of respondents who answered in the affirmative through direct questioning. All of this suggests that analysis based on traditional obtrusive measures of vote buying is a valid and reliable approach in the Indonesian case. Both direct individual and neighbourhood measures are found not to understate the degree of such practices.

One plausible explanation for this lack of social bias is that Indonesian voters seem to be comparatively open about witnessing (and receiving offers of) vote buying. This openness, in turn, appears to be related to vote buying being less stigmatised than it was in the past (see Chap. 6). Despite its formal illegality, vote buying has increasingly become a normal transaction during election and is rarely prosecuted. In the eyes of many voters, an election is no longer viewed as a window of opportunity to express their political preferences, but rather as, borrowing Corstange's term (2012: 483), a 'season of money.' During my 13-month fieldwork at the height of the 2014 election, most politicians lamented the increased pressure on them to engage in vote buying, and they argued that such exchanges have 
become a part of routine politics in Indonesia. They admitted that voters suspected that whoever was elected-regardless from which party he or she originated-was highly likely to quickly forget their constituents after the election. Elections, therefore, are mainly seen as a 'temporary opportunity' for ordinary people to recapture material benefits that politicians have stolen (Kerkvliet, 1991: 231). In the words of Schaffer and Schedler (2007: 26), recipients view offers as “amends for [politicians'] wrongdoings [committed against them] in the past."

However, the initiative to 'normalise' vote buying doesn't only come from voters demanding handouts. To please such voters, and to avoid competing on programmatic grounds, many politicians happily present themselves as personal distributors of patronage, and they find moral justifications to defend this approach. For example, many Islamic politicians justify doing so by quoting religious scholars (kiai). For instance, one successful local candidate in Central Java relied on the advice given by an influential kiai. This kiai stated that if he didn't distribute cash and lost as a result, all his other efforts to win office would be proven meaningless. The kiai reportedly quoted an Arabic script, taken from one of the major textbooks (kitab) studied in Islamic boarding schools, that in his view allowed vote buying. The passage reads: الرشوة حر ام وخرج عن ذلك لاججل عدل (Bribing voters is basically unlawful, but it could be permitted for fairness). Additionally, the kiai - who sat on the advisory board of the candidate's moderate Islamic party - cited an Islamic jurisprudential premise, namely ما لا يتم الواجب إلا به فهو واجب (that without which an obligation cannot be fulfilled is itself obligatory). Based on this proposition, the ultimate goal is the election of a good candidate motivated by a religious cause. If good candidates are reluctant to spend money for vote buying-so the argument goes - and lose as a result, then parliament will be made up only of corrupt politicians (Interview, 12 August 2014). In this view, vote buying is simply an electoral strategy for winning and thus preventing corrupt politicians from taking office. Accordingly, it isn't only justifiable but also necessary.

As a consequence of such efforts at 'normalisation' of vote buying, the stigma attached to it has weakened. During my research, most people talked about vote-buying practices in an open way, indicating that there is little social desirability bias. As Agun Gunandjar Sudarsa of Golkar put it, "vote buying has become public knowledge in Indonesia, [and is] seen as part of a tradition during elections. Indeed, it is illegal on paper, but I am sure the police will not pursue it. Otherwise, the prisons would be full" (Interview, 23 April 2014). Terms such as 'NPWP' (Nomer Piro, Wani Piro, representing the question 'what number on the ballot are you and how much do you dare 
to give?') or GOLPUT (Golongan Penerima Uang Tunai, roughly a 'group of cash recipients' $)^{14}$ circulated widely, pointing to the centrality of such clientelist exchanges. The famous but unsuccessful incumbent candidate from Golkar, Nurul Arifin, stated that in a context where the scale of vote buying is so extensive, the only way to beat co-partisans is by outspending one's internal party rival in terms of distributing cash to voters (Interview, 28 April 2014). Thus, vote buying appeared, borrowing the words of an independent researcher, to be "more massive, vulgar and brutal in the 2014 elections" than ever before (Kompas.com, 21 April 2014).

Far from being increasingly socially stigmatised, then, vote buying in Indonesia is deeply ingrained in the society's fabric. As a result, as argued by Benedict Kerkvliet (1991: 80), for the Philippines, voters see elections as a strategic transaction with power, showing that they too "as voters aren't merely subjects of the seemingly powerful candidates or politicians."

\subsection{Vote Buying in Local Executive Elections}

To further gauge the extent and social acceptability of vote buying in Indonesia, and to compare how such practices play out in different settings, it is important to assess whether different datasets are consistent with the primary data source used in this study. As noted earlier, the previous sections relied heavily on the 2014 post-election, nationwide survey. In the remainder of this chapter, I present a large amount of data drawn from 963 local surveys conducted by my home institutions LSI and Indikator as well as by SMRC between 2006 and 2015. Over the entire period, these three preeminent polling organisations conducted surveys about regional executive elections (pilkada) in 34 provinces and 513 regencies/cities across Indonesia. Though not their primary focus, these surveys included common questions related to vote buying. The relevant question was: "As an effort to win the gubernatorial/regency/mayoral election, certain candidates or brokers typically give money or gifts for people to influence their vote. In your opinion, can the money/gift be considered acceptable or unacceptable?"15 This wording is unobtrusive in that it doesn't inquire about whether vote buying took place or not. But, at least, it may serve to proxy the extent to which vote buying is viewed as acceptable in local executive elections.

\footnotetext{
${ }^{14}$ In normal usage, NPWP is the acronym for 'tax file number,' while GOLPUT denotes those citizens who deliberately abstain from voting.

${ }^{15}$ The wording of the question wasn't always the same. The categories in italics changed according to the level of the territory in which the election took place (i.e. in a province, city, or district).
} 
My focus in analysing this dataset is on inter-regional variation in subnational elections, which I couldn't capture in the national surveys discussed thus far. Note that the population sizes at the district and provincial level are extremely varied, and the frequencies of the surveys were uneven, which could bias the sample to certain regencies/cities. In order to correct this non-random geographic sampling, the weighting scheme is carried out in two stages. In the first stage, the weighting is applied proportionally at the provincial level. In the second stage, the weighting is made within each province to adjust for the over- or under-sampling of voters from certain regencies/cities within provinces. By doing so, the sample is representative at the regency/city level and enables me to generate district-level estimates. Put simply, the formula used to weight observations is:

$$
W_{i j}=\pi_{j} / p_{j}
$$

In which $\pi_{j}=$ proportion of population in each regent/city $j$

$p_{j}=$ proportion of sample in each regency/city $j$

Table 2.10 shows the degree to which vote buying was reported as acceptable by respondents in these local executive election surveys through the period 2006-2015. The acceptability of vote buying at the local level is relatively high, with, overall, four out of ten Indonesians finding it acceptable for politicians or their brokers to distribute cash or gifts as part of their campaigning. Although $60.2 \%$ thought vote buying was unacceptable, the average percentage of respondents who said such practices was acceptable is high. Using similar data from Timor-Leste, for instance, 'only' $32.7 \%$ of the electorate in the country thought that vote buying was acceptable. ${ }^{16}$

Table 2.10 Reported acceptance of vote buying, 2006-2015

\begin{tabular}{|c|c|c|c|}
\hline & & Frequency & $\%$ \\
\hline \multirow[t]{4}{*}{ Valid } & Acceptable & 229,422 & 39.4 \\
\hline & Unacceptable & 350,275 & 60.2 \\
\hline & Don't know/refused to answer & 2130 & 0.4 \\
\hline & Total & 581,828 & 100 \\
\hline
\end{tabular}

${ }^{16}$ Lembaga Survei Timor-Leste (The Timor-Leste Survey Institute) and Lembaga Survei Indonesia (LSI), “Exit Poll: Eleisaun Parlamentar Timor-Leste,” 22 July 2017. 
My study found substantial differences between regions. Those who lived in Java were more likely to consider voting buying to be acceptable. The data show that $46.3 \%$ of respondents from Java didn't have a problem accepting cash or gifts from would-be regional heads. This compared to 'only' $31 \%$ of people from the outer islands who thought vote buying was acceptable. Further, Table 2.11 hints at some intriguing heterogeneity across regions. Relative to other outer island regions, people who lived in Sumatra were less accepting of vote buying in local executive elections.

There are interesting variations across provinces as well. The average percentage of Sumatrans who thought vote buying was acceptable is $28.1 \%$. Some provinces scored significantly above the average, such as Lampung (40.4\%), Bengkulu (38.6\%), and South Sumatra (32.3\%). Meanwhile, some provinces exhibited well below the regional average, such as West Sumatra (13.1\%) and Riau Islands (16.4\%). Given that the data are representative at the district level, we can assess further which regency or city in each province has the highest levels of vote-buying acceptability. In Aceh, for example, despite the province's overall exhibiting acceptance levels well below the Sumatran average, the reported tolerance of vote buying was greatest in Pidie Jaya (70\%), Aceh Singkil (50\%), and East Aceh (36.7\%).

There is also a wide variation in the degree of reported acceptance of vote buying in Java. Among all provinces in Java, voters who lived in Central Java were most likely to be tolerant of vote buying, with $50.9 \%$ of respondents considering vote buying as a normal practice during local elections. Following Central Java are Banten with 46.6\% and East Java with $46.5 \%$. At the other end of the spectrum, Jakarta is among those provinces in Java in which voters were less accepting of vote buying, with only $24.7 \%$ answering in the affirmative. Again, substantial heterogeneity was found within each province. Despite its notoriety as the province that is most tolerant of vote buying, Central Java wasn't homogeneous. Voters

Table 2.11 Reported acceptance of vote buying by region (\%)

\begin{tabular}{llrccc}
\hline & Region & Base & Acceptable & Unacceptable & Don't know \\
\hline \multirow{2}{*}{ \% within regions } & Java & 55.10 & 46.30 & 53.40 & 0.30 \\
& Sumatra & 23.10 & 28.10 & 71.60 & 0.40 \\
& Kalimantan & 5.90 & 33.80 & 65.80 & 0.40 \\
& Sulawesi & 7.90 & 33.10 & 66.60 & 0.30 \\
Total & Others & 7.90 & 35.30 & 63.70 & 1.00 \\
\hline
\end{tabular}

Source: LSI, Indikator, and SMRC historical dataset on sub-national executive elections 
who lived in cities (kota) such as Surakarta, Semarang, and Magelang, for instance, were less accepting of vote buying than those in regencies ( $k a b u$ paten) in that province.

Further, in some cases, my datasets include information on the acceptable price of the votes. Among those who thought vote buying was acceptable, I asked a follow-up question: "How much cash would a candidate need to give for you to find it appropriate to vote for him/her?" As Table 2.12 shows, while responses were quite scattered, the most frequently given answer was 'less than IDR 50,000' (approx. US\$4.40). Note that those who 'don't know' or 'refuse to answer' aren't included in the analysis.

Interestingly, expectations about the appropriate price of a vote in Java were much lower than in the outer islands. For instance, only $12.9 \%$ of respondents who live outside Java ${ }^{17}$ saw it as appropriate to vote for a candidate if given less than IDR 50,000, while a significant proportion of Javanese reported that small sums of money would be satisfactory. Only $9.4 \%$ of respondents in Kalimantan would be happy if given less than IDR 50,000 (Table 2.13).

As I will argue in Chap. 5, the smaller amount that a candidate must spend on 'buying' votes in Java should be largely read in terms of its specific moral economy of gift giving, which is centred around the concept of sangu. In Javanese, sangu means pocket money or food that is usually taken on a journey as supplies. Applied to the context of vote buying, it isn't necessarily the size of the payments that counts, but rather its symbolic appropriateness. As a one-time DPR member who ran in an electoral

Table 2.12 The price of a vote (\%)

\begin{tabular}{llrc}
\hline No. & Price & Frequency & $\%$ \\
\hline 1. & Less than IDR 50,000 & 12,951 & 38.7 \\
2. & IDR 50,000 to 100,000 & 8665 & 25.9 \\
3. & IDR 101,000 to 200,000 & 5315 & 15.9 \\
4. & More than IDR 200,000 & 6551 & 19.6 \\
5. & Total & 33,481 & 100 \\
\hline
\end{tabular}

Source: LSI, Indikator, and SMRC historical dataset on sub-national executive elections

${ }^{17}$ This is the number of the entirety of the outer islands calculated by adding together the rates of those who live in four regions (Sumatra, Kalimantan, Sulawesi, and others) thought the acceptable price of the votes was less than IDR 50,000 and then dividing this total by four. 
Table 2.13 The price of votes by region (\%)

\begin{tabular}{lccccc}
\hline Region & Base (\%) & $\begin{array}{l}\text { Less than IDR } \\
50,000\end{array}$ & $\begin{array}{l}\text { IDR 50,000 to } \\
\text { 100,000 }\end{array}$ & $\begin{array}{l}\text { IDR 101,000 to } \\
\text { 200,000 }\end{array}$ & $\begin{array}{l}\text { More than IDR } \\
\text { 200,000 }\end{array}$ \\
\hline Java & 61.1 & 55.5 & 22.20 & 9.60 & 12.70 \\
Sumatra & 21.50 & 12.60 & 30.60 & 28.00 & 28.90 \\
Kalimantan & 9.90 & 9.40 & 34.80 & 23.80 & 32.00 \\
Sulawesi & 4.70 & 17.30 & 33.80 & 21.80 & 27.10 \\
Others & 2.80 & 12.30 & 25.00 & 22.10 & 40.60 \\
Total & & 38.70 & 25.90 & 15.90 & 19.60 \\
\hline
\end{tabular}

Source: LSI, Indikator, and SMRC historical dataset on sub-national executive elections

district in West Java put it: "If you are seeking people's votes, you have to have good understandings. People who are going to vote for me would be unable to work on voting day. I compensate them for that. It isn't expensive, just souvenirs to 'tie' them so that they don't run to cashed-up rivals" (Interview, 24 April 2014).

In addition to the cultural context, the price of vote buying is greater in local elections where the constituency size is smaller. This helps explain why average expectations of the price of votes in the outer islands were higher because constituencies there are smaller than on densely populated Java. The smaller the population of the district or city, the more a candidate has to spend to buy a vote. The price escalates in some resource-rich, but sparsely populated districts on Kalimantan or in the eastern part of Indonesia. For instance, my study found that $82.1 \%$ of voters in Tana Tidung (North Kalimantan) would consider more than IDR 200,000 (approx. US\$17.80) an appropriate price for a vote. This is one of Indonesia's most resource-rich districts, with significant production of oil, natural gas, and coal, but its population is only about 14,899 , escalating the vote-buying rate for a single candidate to at least IDR 1,000,000 (approx. US\$89) (Informal Communication with a national party leader, 21 May 2014).

Put in a nutshell, the market for votes is huge in Indonesia and vote buying has been pervasive not only in national legislative elections but also in local executive elections. One broker who worked for a winning candidate during the 2017 direct election for regency head in Batang, Central Java, acknowledged that distributing cash handouts was part of his chief strategy because voters saw elections as a 'money harvest' (Interview, 23 January 2017). Prior to the first simultaneous local executive elections in 
December 2015, I interviewed a seasoned broker in East Java. He revealed two important indicators of the intensity of vote buying. First, because cash handouts are usually distributed in plain white envelopes, along with the name card of the candidate, the sales of envelopes in election times increase sharply. ${ }^{18}$ For example, based on the information he received, the sale of envelopes in Sumenep during the 2014 legislative elections rose by $75 \%$, in Sidoarjo by $65 \%$, in Gresik by $60 \%$, Mojokerto by $80 \%$, Ponorogo by $70 \%$, and Trenggalek by $80 \%$. A second anecdotal indication of the prevalence of vote buying is a shortage of small banknotes as election day nears. According to the above broker, most candidates want to change money into smaller denomination banknotes at the bank because vote buying typically takes the form of small payments (usually around IDR 10,000-20,000) (Interview, 5 December 2015).

Overall, as this section has shown, vote buying has been an integral part of Indonesian electoral politics, not only at the national level but also at the local level. Complementing the 2014 national voter survey discussed in previous sections, the sub-national election dataset confirms that vote buying has played a key role in mobilising electoral support. Using the massive dataset of local election surveys that covers the period 2006-2015, I have shown that the level of reported acceptance of vote buying is high, with four out of ten Indonesians not having a problem accepting cash or a gift from candidates for regional government heads. All of this suggests that vote buying has become one of the main instruments of electoral mobilisation in local government contests.

\subsection{Conclusion}

This chapter has explored the prevalence of vote buying in Indonesian election campaigns. Elaborated from a wide range of methods-whether individual, observational, or derived from the list-experiment-the results are mostly congruent with each other. The findings generated from the direct individual and neighbourhood measures as well as from the survey-based experiment are that $25 \%$ of Indonesian voters were exposed to vote buying in the 2014 legislative election when asked directly, $27.4 \%$ when asked via the list-experiment, and $28.9 \%$ when asked through the neighbourhood question. If we use the less obtrusive

\footnotetext{
${ }^{18}$ This observation is based on information he collected from big shops in each regency that sell envelopes on a large scale.
} 
measure without concretely mentioning the 2014 election (as discussed in detail above), the level of vote buying rises slightly to $33 \%$. Hence, the estimated proportion of people engaging in vote buying in Indonesia lies between $25 \%$ and $33 \%$, considering that the difference between one measure to another isn't statistically distinguishable.

In the 2014 legislative election, there were around 187 million registered domestic voters. A range of between $25 \%$ and $33 \%$ would mean an estimated 47 million to 62 million voters nationwide were offered cash or other material benefits in return for their votes. If we rely on the highest estimate, one out of three Indonesian voters was personally exposed to vote buying. It is noteworthy, however, that these figures define a range, rather than a precise point estimate, of vote-buying incidents. In addition, vote buying wasn't only a prominent feature of Indonesia's national legislative elections. My large dataset of local elections across the country found fewer than four out of ten Indonesians thought of vote buying to be an acceptable practice. However, my study found empirical evidence that such practice in general is ubiquitous in Indonesian electoral politics.

Such findings generate more questions. Most obviously, given that vote buying is common but not universal: which voters are targeted in votebuying exchanges? The next chapter provides a comprehensive profile of the typical vote sellers and presents more rigorous analysis to predict the likelihood of a person being offered benefits in exchange for a vote. It does so by testing large number of variables that are generally believed to be the determinants of vote buying.

\section{BiBLIOGRAPHY}

Books, Journal Articles, and Unpublished Papers

Allen, N.W. (2015) Clientelism and the Personal Vote in Indonesia. Electoral Studies 37: 73-85.

Amick, J. (2016) Cash or Carry? Targeting Low Income Voters in Mayoral Election. Paper presented for SEAREG Meeting, 3-4 June, University of Michigan, U.S.

Aspinall, E. (2014) When Brokers Betray: Social Networks and Electoral Politics in Indonesia. Critical Asian Studies 46(4): 545-570.

Aspinall, E. and Sukmajati, M. (eds) (2016) Electoral Dynamics in Indonesia: Money Politics, Patronage and Clientelism at the Grassroots. Singapore: NUS Press. 
Aspinall, E. and As'ad, M.U. (2015) The Patronage Patchwork: Village Brokerage Networks and the Power of the State in an Indonesian Election. Bijdragen tot de Taal-, Land- en Volkenkunde 171: 165-195.

Aspinall, E., Rohman, N., Hamdi, A.Z., Rubaidi, and Triantini, Z. (2017) Vote Buying in Indonesia: Candidate Strategies, Market Logic and Effectiveness. Journal of East Asian Studies 17: 1-27.

Blair, G. and Imai, K. (2012) Statistical Analysis of List Experiments. Political Analysis 20: 47-77.

Brusco, V., Nazareno, M., and Stokes, S. (2004) Vote Buying in Argentina. Latin American Research Review 39(2): 66-88.

Choi, N. (2007) Local Elections and Democracy in Indonesia: The Riau Archipelago. Journal of Contemporary Asia 37(3): 326-345.

Corstange, D. (2012) Vote Trafficking in Lebanon. International Journal Middle East Studies 44: 483-505.

De Jonge, C.P.K. (2015) Who Lies about Electoral Gifts? Experimental Evidence from Latin America. Public Opinion Quarterly 79(3): 710-739.

Gallego, J. and Wantchekon, L. (2012) Chapter 7 Experiments on Clientelism and Vote-Buying. In: D. Serra and L. Wantchekon (eds) New Advances in Experimental Research on Corruption (Research in Experimental Economics, Volume 15). Emerald Group Publishing Limited, 177-212.

Gonzalez-Ocantos, E., de Jonge, C.K., Meléndez, C., Osorio, J., and Nickerson, D.W. (2012) Vote Buying and Social Desirability Bias: Experimental Evidence from Nicaragua. American Journal of Political Science 56(1): 202-217.

Hicken, A. (2007) How Effective are Institutional Reforms? In: F.C. Schaffer (ed) Elections for Sale: The Causes and Consequences of Vote Buying. Colorado: Lynne Rienner Publisher, Inc.

Jensen, P.S. and Justesen, M.K. (2014) Poverty and Vote Buying: Survey-based Evidence from Africa. Electoral Studies 33: 220-232.

Kerkvliet, B.J. (1991) Understanding Politics in a Nueva Ecija Rural Community. In: B. Kerkvliet and R. Mojares (eds) From Marcos to Aquino: Local Perspectives on Political Transition in the Philippines. Honolulu: University of Hawaii Press.

Kramon, E. (2013) Vote Buying and Accountability in Democratic Africa. PhD dissertation, UCLA, CA, USA.

Mujani, S., Liddle, R.W., and Ambardi, K. (2012) Kuasa Rakyat: Analisis tentang Perilaku Memilih dalam Pemilihan Legislatif dan Presiden Indonesia PascaOrde Baru. Bandung: Mizan.

Pulse Asia. 2013. On the 2013 Elections: Observations and Select Survey Results. Presented at Workshop of Money Politics, Patronage and Electoral Dynamics, Yogyakarta. 13-15 December 2013.

Schaffer, F.C. (2007) Elections for Sale: The Causes and Consequences of Vote Buying. Colorado: Lynne Rienner Publisher, Inc. 
Schaffer, F.C. and Schedler, A. (2007) What is Vote Buying? In: F.C. Schaffer (ed) Elections for Sale: The Causes and Consequences of Vote Buying. Boulder: Lynne Reinner.

Stokes, S.C. (2007) Is Vote Buying Undemocratic? In: F.C. Schaffer (ed) Elections for Sale: The Causes and Consequences of Vote Buying. Colorado: Lynne Rienner Publisher, Inc.

Tawakkal, G., Suhardono, W., Garner, A., and Seitz, T. (2017) Consistency and Vote Buying: Income, Education, and Attitudes about Vote Buying in Indonesia. Journal of East Asian Studies 17(3): 313-329.

The Latin American Public Opinion Project (LAPOP) Americas Barometer. (2010) http://www.vanderbilt.edu/lapop/ab2010.php. Accessed 24 October 2015.

Wang, C.S. and Kurzman, C. (2007) The Logistics: How to Buy Votes. In: F.C. Schaffer (ed) Elections for Sale: The Causes and Consequences of Vote Buying. Boulder: Lynne Reinner.

Weiss, M. (2013) General Election 2013 Survey Results. Material presented at Workshop of Money Politics, Patronage and Electoral Dynamics, 13-15 December, Yogyakarta.

\section{Articles And Reports}

KPU. (2014) Partisipasi Pemilih pada Pemilu 2014. Viewed at http://www.kpu. go.id/koleksigambar/Partisipasi_Pemilih__ pada_ Pemilu2014_ Studi_ Penjajakan.pdf. Accessed 1 November 2014.

Open Access This chapter is licensed under the terms of the Creative Commons Attribution 4.0 International License (http://creativecommons.org/licenses/ by $/ 4.0 /$ ), which permits use, sharing, adaptation, distribution and reproduction in any medium or format, as long as you give appropriate credit to the original author(s) and the source, provide a link to the Creative Commons licence and indicate if changes were made.

The images or other third party material in this chapter are included in the chapter's Creative Commons licence, unless indicated otherwise in a credit line to the material. If material is not included in the chapter's Creative Commons licence and your intended use is not permitted by statutory regulation or exceeds the permitted use, you will need to obtain permission directly from the copyright holder.

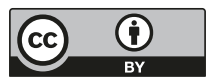

